\title{
PEMANFAATAN TANAH HUTAN SEBAGAI ALTERNATIF PENGOBATAN TRADISIONAL MASYARAKAT KAMPUNG MAPURA KABUPATEN MAYBRAT
}

\section{(The Use Of Forest Soil That Intended For Alternative Medicine Among Local Inhabitants of Mapura Village, District of Maybrat)}

\author{
Federosa Kambuaya ${ }^{1}$ Matheus Beljai ${ }^{1 凶}$ dan Charly B. Wanggai ${ }^{1}$ \\ Jurusan Kehutanan, Fakultas Kehutanan Universitas Papua Manokwari, Papua Barat, \\ 98314. Tlp/Fax: +62986211065. \\ ${ }^{\square}$ Penulis Korespondensi: Email: beljaimatheus@gmail.com \\ Diterima: 10 Juli 2019| Disetujui: 02 Sep 2019
}

\begin{abstract}
Abstrak
Penelitian ini bertujuan untuk mengetahui pemanfaatan jenis tanah hutan sebagai alternatif pengobatan tradisional bagi masyarakat Kampung Mapura Kabupaten Maybrat. Metode penelitian deskriptif dengan teknik observasi lapangan dan wawancara semi struktural dilakukan untuk memperoleh data tanah dan informasi dari responden. Analisis lanjutan sampel tanah yang meliputi tekstur, $\mathrm{pH}$, struktur dan kadar air juga dilakukan guna mengetahui komposisi dan karaktersitik dari jenis tanah yang digunakan. Hasil penelitian menunjukan bahwa masyarakat memanfaatkan 1 (satu) jenis tanah yang digunakan sebagai pengobatan yaitu jenis tanah liat. Bagian tanah yang digunakan sebagai pengobatan ialah permukaan tanah maupun bagian dalam tanah dengan cara menggali. Secara umum, struktur tanah yang diperoleh antara lain granular, gumpal bersudut, gumpal membulat dengan tekstur lempung, lempung liat berpasir serta memiliki kisaran kadar air tanah antara $13,18 \%$ - 23,26\% dan kisaran nilai $\mathrm{pH}$ tanah antara 6,1 - 6,84. Penyakit yang disembuhkan ialah sebanyak 8 jenis penyakit. Metode pengobatan ini telah berlangsung lama dan secara hirarki diturunkan dari generasi ke generasi dalam keberadaban masyarakat Maybrat di Kampung Mapura.
\end{abstract}

Kata kunci: tanah liat, pengobatan alternatif, tranfer pengetahuan, karakteristik tanah

\begin{abstract}
This study highlights the usage of forest soil as an alternative traditional medicinal treatment by local inhabitants of Mapura village, District of Maybrat. A Descriptive method by way of field observation technique and semi-structural interview are carried out to acquire soil data and information from respondents. Further analysis of soil sample such as texture, soil $\mathrm{pH}$, structure and moisture content of the soil are also determined its composition and soil characteristics. The result indicated that the locals have been extracted only one soil type which was clay type. Topsoil and partly digged parts have been preferred to be used for medicinal treatment. In general, the soil structure was characterized as granular, angular blocky, and sub angular blocky with the texture characteristics of clay and sandy clay loam and owed moisture content ranging from $13.18 \%-23.26 \%$ as well as soil pH ranging from $6.1-6.84$. So far, there was 8 common diseases have been healing from the treatment. Such a method has been around the local
\end{abstract}


inhabitants of Maybrat in Mapura village for a long period of time and it was likely passed over generations.

Keywords: clay soil, alternative medicine, knowledge transfer, soil characteristic

\section{PENDAHULUAN}

Tanah adalah suatu benda alam yang terdapat di permukaan kulit bumi, yang tersusun dari bahan-bahan mineral sebagai hasil pelapukan batuan dan bahan-bahan organik sebagai hasil pelapukan sisa-sisa tumbuhan dan hewan, yang merupakan medium atau tempat tumbuhnya tanaman dengan sifat-sifat tertentu, yang terjadi akibat dari pengaruh kombinasi faktor-faktor iklim, bahan induk, jasad hidup, bentuk wilayah dan lamanya waktu pembentukan (Yulipriyanto 2010).

Pengobatan tradisional sebagai budaya bangsa merupakan suatu upaya penyembuhan dan perawatan cara lain di luar dari ilmu kedokteran. Sistem pengobatan moderen telah berkembang pesat dimasa sekarang dan telah menyentuh hampir semua lapisan masyarakat. Tetapi perkembangan medis atau model selalu diikuti dengan pengobatan tradisional. Disamping itu, (Dermawan 2013) 57,7\% penduduk Indonesia melakukan pengobatan sendiri, $31,7 \%$ menggunakan obat tradisional, dan $9,8 \%$ memilih cara pengobatan tradisional. Sedangkan pada tahun 2004 penduduk Indonesia yang melakukan pengobatan sendiri meningkat menjadi $72,44 \%$ dimana $32,87 \%$ menggunakan obat tradisional. Artinya jumlah ini akan semakin meningkat walaupun pengobatan moderen di Indonesia tidak kalah dengan luar negeri. Sehingga pengobatan tradisional ini perlu diketahui oleh banyak orang.
Menurut Asmino (1995) pengobatan tradisional dibedakan menjadi dua macam yaitu pertama dengan cara penyembuhan tradisional (traditional healing) yang terdiri dari pijatan, kompres dan akupuntur. Kedua dengan cara obat tradisional (traditional drugs) yaitu menggunakan bahan-bahan yang telah tersedia dari alam seperti halnya tanaman, hewan, sumber mineral atau garam-garam serta air.

Pengetahuan dalam pengobatan tradisional di tanah papua pada umumnya telah berlangsung sejak ratusan tahun yang lalu. Berdasarkan perbedaan keadaan alam papua maka kemungkinankemungkinan hidup masing-masing daerah dalam pengobatan berbeda-beda. Suku Maybrat merupakan salah satu suku di Papua yang mendiami di daerah kepala burung pulau papua, dan masyarakatnya juga memanfaatkan bagian-bagian tumbuhan dan tanah sehari-hari sebagai bahan obat tradisional.

Kabupaten Maybrat merupakan kabupaten pemekaran di tahun 2002. Orang Maybrat mendiami 8 (delapan) wilayah pemerintahan Distrik ialah : distrik Aifat Timur, distrik Aifat, distrik Aitinyo, distrik Moswaren, distrik Ayamaru, distrik Mare, distrik Wayer dan distrik Ayamaru Utara di dalam daerah pemerintahan Kabupaten Sorong Selatan. Pada masa ini orang Maybrat mendiami sebelas wilayah pemerintahan distrik meliputi : Distrik Aifat, Aifat Utara, Aifat Timur, Aifat Selatan, Aifat Barat, Aitinyo, Aitinyo Utara, Ayamaru, Ayamaru Utara, Ayamaru Timur dan 
distrik Mare di dalam daerah pemerintahan kabupaten Maybrat. Dari data 11 (sebelas) distrik tersebut telah dimekarkan menjadi 24 Distrik yang salah satunya adalah Distrik Ayamaru Utara Timur, yang merupakan Distrik pemekaran dari Kabupaten Maybrat. Berdasarkan Surat Keputusan Bupati Kabupaten Maybrat tertanggal 05 Maret Nomor 06 Tahun 2010 (Badan Perencanaan Pembangunan Daerah Papua Barat 2010). Kabupaten Maybrat yang beribu Kota di Aifat (Kumurkek).Jumlah kampung yang terdapat di Distrik Ayamaru Utara Timur adalah 8 kampung, yaitu 2 (dua) kampung induk adalah kampung Mapura dan kampung Suwiam.Sedangkan 6 (enam) kampung pemekaran yang lainnya adalah Kampung Fraboh, Tomase, Karfa, Kosah, Kona dan Kampung Nauwita.

Daerah ini masih menggunakan pengobatan tradisional yang dipercayai sebagai warisan penyembuhan sakit penyakit. Pengobatan dengan menggunakan tanah sebagai bahan utama untuk orang sakit.Tanah dipercaya oleh masyarakat suku Maybrat bisa mengobati penyakit karena manusia pertama dalam Alkitab adalah Adam dan Hawa diciptakan dari tanah. Sehingga masyarakat di Distrik Ayamaru Utara Timur Kabupatem Maybrat mengartikan bahwa tanah sebagai bahan obat tradisional selain obat-obat moderen atau medis. Penelitian ini bertujuan untuk mengetahui pemanfaatan tanah sebagai alternatif pengobatan tradisional bagi masyarakat Kampung Mapura Kabupaten Maybrat.

\section{METODE PENELITIAN}

Penelitian ini dilaksanakan selama 1 bulan yaitu dari bulan Juli s/d Agustus tahun 2018 yang bertempat di Kampung Mapura. Guna analisis lanjutan sampel tanah, penelitian ini juga dilaksanakan di Laboratorium Tanah Fakultas Pertanian UNIPA Manokwari.

\section{Metode Penelitian}

Penelitian ini menggunakan metode deskriptif dengan teknik observasi lapangan dan wawancara. Observasi lapangan dilakukan melalui pengumpulan, pengamatan, dan pengukuran terhadap tanah yang digunakan sebagai obat dalam pengobatan tradisional. Sedangkan wawancara dilakukan terhadap masyarakat yang pernah menggunakan tanah sebagai obat tradisional untuk menyembuhkan sakit penyakit.

\section{Variabel Pengamatan}

Variabel yang diamati dalam penelitian ini terdiri dari variabel utama dan penunjang. Variabel utama meliputi: karakteristik tanah, proses pemanfaatan tanah untuk pengobatan. Sedangkan variabel penunjang meliputi pola transfer pengetahuan tradisional dan kondisi lokasi penelitian.

\section{Sumber dan Jenis Data}

Data yang dikumpulkan dalam penelitian ini bersumber dari data primer dan sekunder. Data primer diperoleh dari hasil wawancara dan observasi lapangan (pengambilan contoh sampel tanah) dan pengujian di laboratorium. Sedangkan data sekunder diperoleh dari berbagai sumber berupa hasil penelitian, laporan, atau sumber internet, khususnya yang berkaitan dengan tujuan penelitian. Data sekunder meliputi data lokasi penelitian, peta lokasi, topografi, jenis tanah, iklim, serta data penunjang lainnya. 


\section{Tahapan Penelitian}

Penelitian ini terdiri dari beberapa tahap yang dapat diuraikan sebagai berikut:

\section{Penentuan Responden}

Responden dalam penelitian ini terdiri dari 2 (dua) kelompok, yaitu responden kunci (key respondent) dan responden umum (common respondent). Responden kunci ialah peramu obat atau orang yang dipercaya menggunakan tanah sebagai media untuk pengobatan (dokter kampung). Sedangkan responden umum ialah masyarakat yang pernah berobat dengan menggunakan media tanah. Penentuan responden umum dilakukan dengan menggunakan metode snowball.

2. Pengumpulan Sampel Tanah di Lapangan

Pengumpulan sampel tanah dilakukan berdasarkan wawancara dengan responden kunci. Sampel tanah yang diambil ialah tanah yang digunakan untuk pengobatan. Jumlah sampel tanah yang diambil sebanyak $\pm 1 \mathrm{~kg}$ untuk setiap sampel dari standar pengambilan sampel tanah.

3. Pengamatan Sampel di Laboratorium Pengamatan sampel tanah dilakukan terhadap 4 (empat) karakter tanah yaitu tekstur, struktur, kadar air, dan $\mathrm{pH}$ tanah. Prosedur pengamatan masing-masing karakter tersebut diuraikan sebagai berikut:

a. Pengamatan tekstur tanah

Pengamatan terhadap tekstur tanah dilakukan dengan menimbang sampel tanah yang telah diambil yaitu 10 (sepuluh) sampel tanah ukuran $<2 \mathrm{~mm}$. Selanjutnya sampel dimasukan ke dalam gelas piala 800 ml dan ditambahkan $50 \mathrm{ml}$ larutan
$\mathrm{H}_{2} \mathrm{O}_{2} \quad 10 \%$ lalu dibiarkan selama satu malam. Pada hari berikutnya, sampel tersebut ditambah dengan $25 \mathrm{ml}$ larutan $\mathrm{H}_{2} \mathrm{O}_{2} 30 \%$, kemudian dipanaskan (dididihkan) hingga tidak berbusa.

Sampel tersebut selanjutnya ditambahkan $180 \mathrm{ml}$ air bebas ion dan $20 \mathrm{ml}$ larutan HCI 2N, lalu campuran sampel tersebut dipanaskan di atas pemanas listrik selama lebih kurang 10 menit. Selanjutnya sampel tersebut diangkat dan dibiarkan hingga agak dingin lalu diencerkan dengan air bebas ion menjadi $700 \mathrm{ml}$. Selanjutnya sampel dicuci dengan air bebas ion menggunakan penyaring bekefield atau diendaptuangkan sampai bebas asam, kemudian ditambah $10 \mathrm{ml}$ larutan peptisator $\mathrm{Na} 4 \mathrm{P} 2 \mathrm{O} 2$ 4\%. Proses berikutnya ialah memisahkan pasir, debu, dan liat, yang dilakukan sebagai berikut:

- Pemisahan pasir

Suspensi tanah yang telah diberi peptisator diayak dengan ayakan 50 mikron sambil dicuci dengan air bebas ion. Filtrat ditampung dalam silinder $500 \mathrm{ml}$ untuk pemisahan debu dan liat. Butiran yang tertahan ayakan dipindahkan ke dalam pinggan alminium yang telah diketahui bobotnya dengan air bebas ion menggunakan botol semprot. Keringkan (hingga bebas air) dalam oven pada suhu $150{ }^{\circ} \mathrm{C}$, didinginkan dalam eksikator dan timbang (berat pasir $=$ A g).

- Pemisahan debu dan liat Fitrat dalam silinder diencerkan menjadi $500 \mathrm{ml}$, diaduk selama 1 
menit dan dipipet sebanyak 20 $\mathrm{ml}$ ke dalam pinggan aluminium. Fitrat dikeringkan pada suhu 105 ${ }^{\circ} \mathrm{C}$ (biasanya 1 menit), didinginkan dalam eksikator dan ditimbang (berat debu + liat + pepsitor = $\mathrm{B}$ g). Untuk pemisahan liat diaduk lagi selama 1 menit lalu dibiarkan selama 3 jam 30 menit pada suhu kamar. Suspensi liat dipipet sebanyak $20 \mathrm{ml}$ pada kedalaman $5,2 \mathrm{~cm}$ dari permukaan cairan dan dimasukan kedalam pinggan aluminium. Suspensi liat dikeringkan dalam oven pada suhu $105^{\circ} \mathrm{C}$, didinginkan dalam eksikator dan ditimbang (berat liat + pepsitor $=\mathrm{C} \mathrm{g}$ ).

b. Pengamatan $\mathrm{pH}$ tanah

Pengamatan terhadap $\mathrm{pH}$ tanah dilakukan sebagai berikut:

Sampel tanah dan air aquadest disiapkan dengan perbandingan 1:1 lalu dimasukan dalam gelas kimia dan diaduk hingga benar-benar merata. Sampel tersebut dibiarkan beberapa menit hingga campuran air dan tanah tadi memisah (tanahnya mengendap), sehingga airnya terlihat hangat jernih masukan ujung kertas lakmus atau $\mathrm{pH}$ indikator ke dalam campuran tadi (sekitar 1 menit) tetapi jangan sampai mengenai tanahnya. Selanjutnya tunggu beberapa saat sampai kertas lakmus atau $\mathrm{pH}$ indikator berubah warna. Setelah warnanya stabil, cocokan warna yang diperoleh oleh kertas lakmus atau $\mathrm{pH}$ indikator. Dengan demikian $\mathrm{pH}$ tanah tersebut dapat diketahui.

c. Pengamatan struktur tanah
Proses pengamatan terhadap struktur tanah dilakukan sebagai berikut:

Sampel tanah atau gumpalan tanah diambil (diusahakan agar sedapat mungkin dalam keadaan lembab) dengan diameter $\pm 10 \mathrm{~cm}$. Gumpalan tanah tersebut dipecahkan dengan cara menekan dengan jari (pecahan dari gumpalan tersebut merupakan agregat atau gabungan agregat).

Selanjutnya ditentukan struktur tanahnya. Bentuk-bentuk struktur tanah, yang ditentukan oleh bentuk agregat adalah: (1) remah (crumb); (2) granular; (3) lempeng (platy), jika sumbu $\mathrm{X}>\mathrm{Y}$; (4) prisma (prismatik), jika sumbu $\mathrm{Y}>\mathrm{X}$, tapi ujungnya membulat; (5) gumpal bersudut (angular blocky), jika sumbu $\mathrm{X}=\mathrm{Y}=\mathrm{Z}$ dan ujungnya membulat; (6) lepas atau butir tunggal (loose); dan (7) masif (pejal).

d. Pengamatan kadar air

Pengamatan terhadap kadar air tanah dilakukan sebagai berikut:

Sampel tanah diambil sebanyak 30 gr lalu dimasukkan ke dalam oven dengan suhu $\pm 105{ }^{\circ} \mathrm{C}$ dan dibiarkan selama 24 jam. Setelah 24 jam sampel tersebut dikeluarkan dan ditimbang kemudian dicatat perubahan penurunan beratnya. Selanjutnya dilakukan penimbangan hingga menemukan berat konstan.

\section{Analisis Data}

Data hasil penelitian selanjutnya dianalisis secara deskritif dan ditampilkan dalam bentuk gambar dan tabel. 


\section{HASIL DAN PEMBAHASAN}

\section{Karakter Tanah Yang Digunakan Untuk Pengobatan}

Dari hasil penelitian diketahui bahwa jenis tanah yang digunakan secara tradisional untuk pengobatan masyarakat di Kampung Mapura ialah jenis tanah liat. Tanah tersebut diambil dari bagian permukaan tanah dan merupakan jenis tanah yang diketahui dan dipercaya sebagai salah satu media (obat) yang memiliki khasiat sangat baik untuk pengobatan berbagaisakit penyakit.

Secara tradisional jenis tanah tersebut mudah untuk dikenal, namun secara ilmiah perlu pembuktian umum untuk dapat menjelaskan karakteristik tanah yang digunakan sebagai media pengobatan (sebagai obat tradisional). Oleh sebab itu, perlu diketahui beberapa karakter tanah tersebut melalui hasil analisis di laboratorium.

Secara keseluruhan, karakter tanah untuk pengobatan tradisional di Kampung Mapura dapat dijelaskan melalui 4 (empat) macam karakter, yaitu struktur tanah, tekstur tanah, kadar air tanah, dan sifat kemasaman tanah ( $\mathrm{pH}$ tanah). Keempat karakter tanah tersebut ditampailkan dalam tabel 1.

Tabel 1. Karakteristik tanah yang digunakan untuk pengobatan di Kampung Mapura

\begin{tabular}{|c|c|c|c|c|c|}
\hline Sampel & Ukuran & Struktur & Tekstur & Kadar air $(\%)$ & pH Tanah \\
\hline \multicolumn{6}{|c|}{ A. Karakter Tanah yang digunakan Untuk Pengobatan Tradisional } \\
\hline S-I & 2 Genggam & Granular & Lempung & 23,26 & 6,1 Agak Masam \\
\hline S-II & 3 Genggam & $\begin{array}{l}\text { Gumpal } \\
\text { Bersudut }\end{array}$ & $\begin{array}{c}\text { Lempung Liat } \\
\text { Berpasir }\end{array}$ & 17,98 & 6,37 Agak Masam \\
\hline S-III & 2 Genggam & $\begin{array}{c}\text { Gumpal } \\
\text { Membulat }\end{array}$ & $\begin{array}{l}\text { Lempung } \\
\text { Berpasir }\end{array}$ & 13,18 & 6,42 Agak Masam \\
\hline S-IV & 2 Genggam & $\begin{array}{l}\text { Gumpal } \\
\text { Membulat }\end{array}$ & $\begin{array}{c}\text { Lempung Liat } \\
\text { Berpasir }\end{array}$ & 22,11 & 6,84 Netral \\
\hline \multicolumn{6}{|c|}{ B. Karakter Tanah yang Tidak digunakan Untuk Pengobatan Tradisional } \\
\hline S-V & & $\begin{array}{l}\text { Massive/ } \\
\text { Lengket }\end{array}$ & $\begin{array}{l}\text { Lempung } \\
\text { Berliat }\end{array}$ & 84,34 & 6,45 Agak Masam \\
\hline S-VI & & Granular & $\begin{array}{l}\text { Lempung } \\
\text { Berpasir }\end{array}$ & 28,36 & 6,72 Netral \\
\hline
\end{tabular}

Sumber : Hasil analisis laboratorium, 2018

Setiap karakter tersebut dapat diuraikan sebagai berikut :

\section{Struktur}

Struktur tanah yang digunakan sebagai media pengobatan ialah bervariasi sesuai dengan sampel yang dianalisis. Dalam penelitian ini, sampel tanah yang diambil dan dianalisis ada 4 (empat) sampel, yaitu Sampel I, II, III, dan IV. Untuk sampel pertama (S-I), karakter struktur tanahnya berbentuk granular, sedangkan sampel kedua (S-II), karakter struktur tanahnya berbentuk gumbal bersudut. Untuk sampel ketiga (S-III) dan keempat (S-IV), karakter struktur tanahnya sama-sama berbentuk gumbal membulat.

Sedangkan tanah yang tidak digunakan sebagai media pengobatan terdapat pada sampel kelima (S-V) struktur tanah berbantuk massive/lengket, dan sampel keenam (S-VI) berbentuk granular. Jadi yang memiliki struktur tanah yang sama 
yaitu sampel ketiga dan sampel keempat yaitu berbentuk gumbal membulat, sedangkan struktur tanah yang sama juga terdapat pada sampel pertama tanah yang digunakan sebagai pengobatan dan sampel keenam tanah yang tidak digunakan sebagai media pengobatan srtuktur tanahnya berbentuk granular.

\section{Tekstur}

Tekstur tanah merupakan bagian dari klasifikasi secara kualtatif mengenai kondisi suatu tanah berdasarkan tekstur fisiknya. Berikut ini adalah hasil analisis di laboratorium menunjukan bahwa tanah yang digunakan sebagai media pengobatan pada sampel pertama (S-I) tekstur tanah berbentuk lempung, sampel kedua (S-II) berbentuk lempung liat berpasir, sampel ketiga (S-III) berbentuk lempung berpasir, sampel keempat (S-IV) berbentuk lempung liat berpasir.

Sedangkan tanah yang tidak digunakan sebagai media pengobatan pada sampel kelima (SN-V) tekstur tanah berbentuk lempung berliat, dan sampel keenam (SVI) berbentuk lempung berpasir. Jadi yang memiliki tekstur tanah yang sama

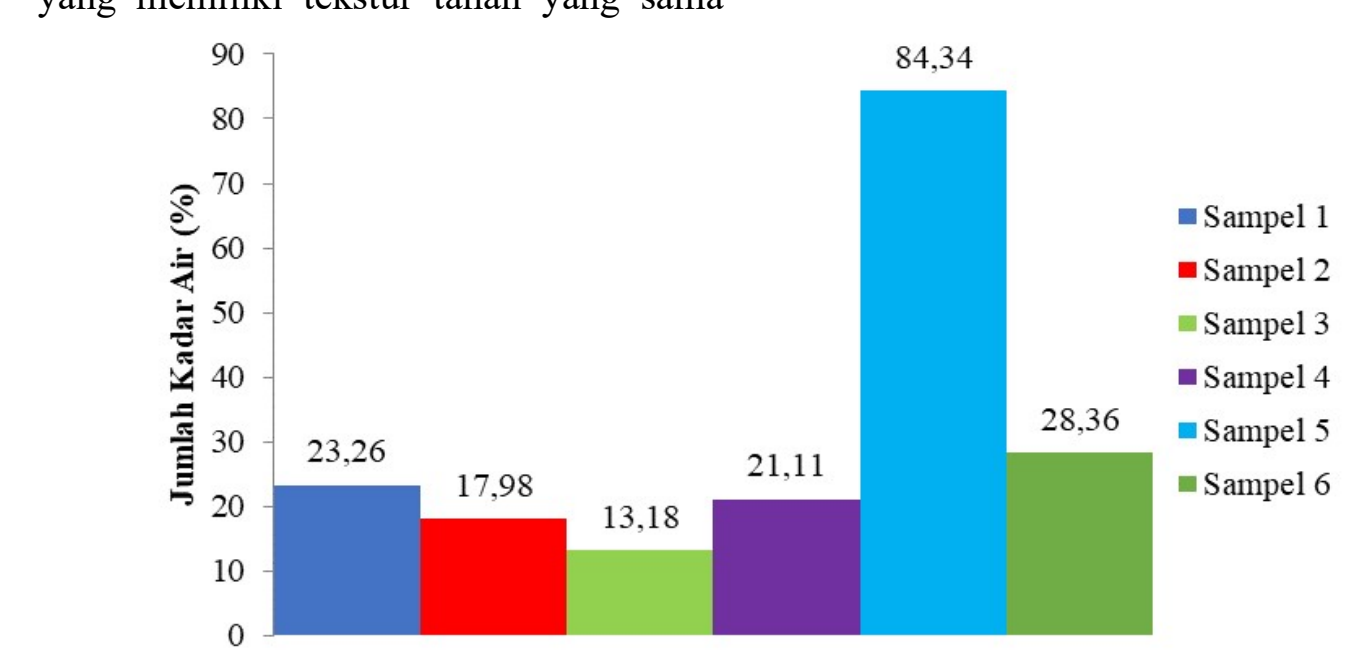

Gambar 1. Grafik variasi persentase nilai kadar air sampel tanah terdapat pada sampel kedua dan sampel keempat, yaitu berbentuk lempung liat berpasir.

\section{Kadar Air}

Hasil analisis tentang kadar air menunjukkan bahwa ukuran pengambilan tanah dalam pengobatan yang mana ukuran sampel pertama (S-I) hanya dua genggam tangan, sampel kedua (S-II) tiga genggam tangan oleh bapak Saul Basna, sedangkan sampel ketiga (S-III) dan, sampel keempat (S-IV), dua genggam tangan oleh Bapak saul Yumame. Pada (S-I) memiliki kadar air $(23,26 \%)$ untuk dosis anak- anak, (S-II) memiliki kadar air $(17,98 \%)$ dosis orang dewasa dan lanjut usia, sampel ketiga (S-III) memiliki kadar air $(13,18 \%)$ dan sampel keempat (S-IV) memiliki kadar air (22,11\%). Pada sampel ketiga (S-III) dan sampel keempat (S-IV) memiliki dosis yang sama yaitu dilakukan terhadap anak-anak, orang dewasa maupun lanjut usia. Maka dari jumlah kadar air pada sampel tanah untuk pengobatan yang lebih banyak kadar air adalah dosis anak-anak. 
Sedangkan tanah yang tidak digunakan sebagai pengobatan, terdapat pada sampel sampel kelima (S-V) oleh bapak Saul Basna, memiliki kadar air (84,34\%), dan sampel keenam (S-VI) oleh Bapak Saul Yumame memiliki kadar air (28,36\%). Jadi sampel tanah yang tidak digunakan sebagai pengobatan ini yang memiliki kadar air lebih banyak adalah dari sampel kelima (S-V).

Sampel tanah yang memiliki kadar air lebih tinggi, karena tempat pengambilan sampel tanah agak dekat dengan air/kali. Sehingga ia memiliki kadar air yang lebih tinggi dari sampel tanah yang lain.

\section{Sifat Kemasaman ( $p H)$}

Hasil analisis tentang $\mathrm{pH}$ tanah menjelaskan bahwa pengambilan tanah dalam pengobatan, yang mana sampel pertama (S-I) dua genggam tangan, sampel kedua (S-II) tiga genggam tangan oleh bapak Saul Basna, sedangkan sampel ketiga (S-III) dan sampel keempat (S-IV) dua genggam tangan oleh bapak Saul
Yumame. Pada sampel (S-I) memiliki pH tanah $(6,1)$ agak masam, sampel kedua (S-II) memiliki $\mathrm{pH}$ tanah $(6,37)$ agak masam, sampel ketiga (S-III) memiliki $\mathrm{pH}$ tanah $(6,42)$ agak masam, sampel keempat (S-IV) memiliki pH tanah $(6,84)$ Netral. Dari grafik $\mathrm{pH}$ tanah yang digunakan dalam pengobatan anak-anak lebih rendah (lebih masam) dari pada orang dewasa, orang tua maupun lanjut usia. Sedangkan tanah yang tidak digunakan sebagai pengobatan memiliki $\mathrm{pH}$ lebih masam $(6,45)$ disekitar sampel kelima (S-V) oleh Bapak Saul Basna, sedangkan yang lebih rendah/netral yaitu $(6,72)$ pada sampel keenam.

Tanah yang digunakan sebagai media pengobatan, tanah berwarna kuning. Ordo tanah yang digunakan sebagai pengobatan, tanah berjenis ordo Oxisol yang mempunyai horizon penciri oksik atau kandik, dan kandungan liat yang tinggi.

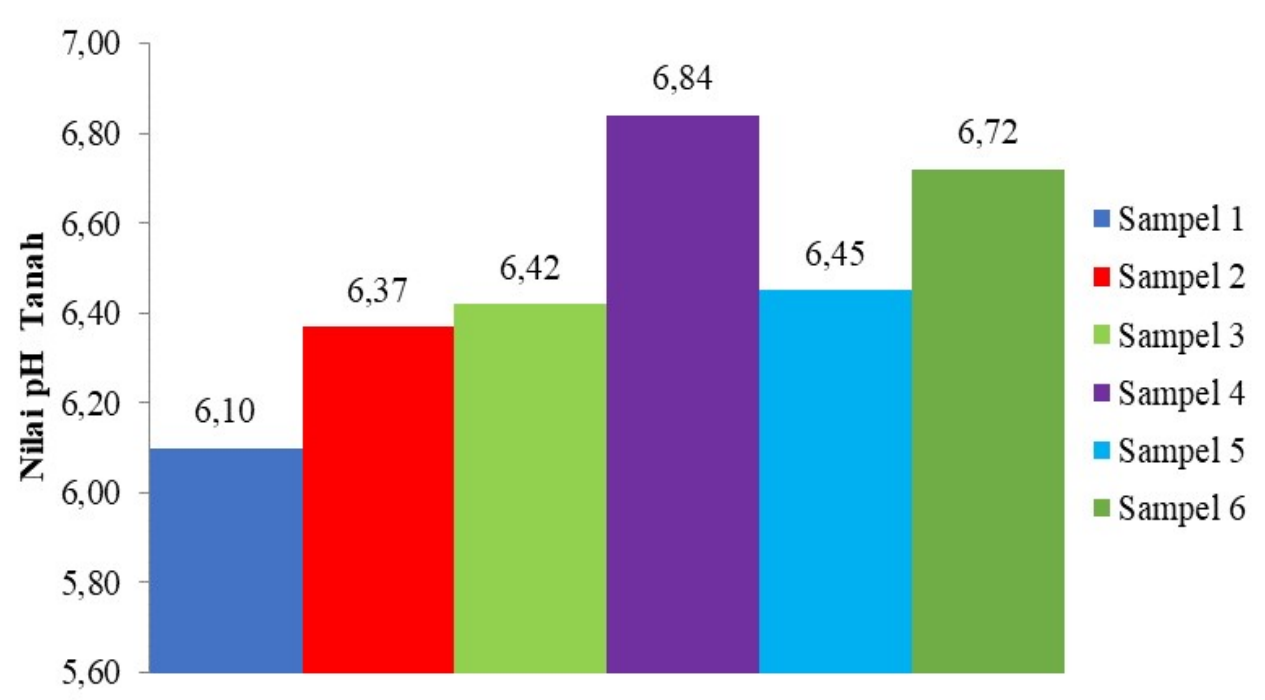

Gambar 2. Grafik variasi nilai derajat keasaman sampel tanah 


\section{Proses Pemanfaatan Tanah Untuk Pengobatan}

Proses Pengambilan dan Pengolahan Tanah sebagai Obat

Tanah yang diambil untuk pengobatan tradisional bervariasi dan tergantung pada bagian tanah yang dimanfaatkan. Proses pengambilan tanah ialah dengan terlebih dahulu menentukan tanah yang biasa digunakan, kemudian mengambil tanah menggunakan tangan. Selanjutnya tanah yang sudah diambil diletakan di atas permukaan daun lalu ditutup agar tetap basah.

Waktu yang digunakan untuk pengambilan tanah bervariasi dan tergantung dari kebutuhan pengobatan sakit yang dialami. Oleh sebab itu, waktu yang digunakan ialah pada pagi hari, siang, sore, atau pada malam hari sesuai dengan kebutuhan sakit/jenis penyakit yang dialami oleh masyarakat di Kampung Mapura.

Masyarakat Kampung Mapura dalam meramu/membuat pengobatan tradisional dari tanah, pada umumnya dilakukan secara sederhana. Dimana dari jenis yang diperoleh, sebagai jenis tersebut hanya dapat diolah secara langsung pada tempat atau lokasi pengambilan sampel tanah. Cara meramu pengobatan tradisional yaitu tanah yang sudah diambil dipijitpijit tujuan agar halus, selanjutnya di percik setelah itu dibasahi dengan air pada tanah tujuan agar mudah untuk digosok/dioleskan pada tubuh yang sakit atau diobati.

Proses Pengobatan dan Penyembuhan Sakit

Ramuan yang digunakan pada pengobatan tradisional di Kampung Mapura adalah ramuan yang berasal dari tanah dan juga dari unsur nabati (tumbuh- tumbuhan). Sumber ramuan tanah yang digunakan umumnya diambil sekitar Kampung Mapura.

Pemakaian tanah yang digunakan sebagai pengobatan tradisional oleh masyarakat Kampung Mapura memiliki dosis dan waktu penggunaan yang berbeda. Namun pada dosis anak-anak sedikit berbeda dengan dosis orang dewasa maupun lanjut usia. Dosis anak memiliki berat tanah $\pm 409,1$ gr hanya dengan 2 genggam tangan pengambilan sampel tanah, sedangkan dosis orang dewasa maupun lanjut usia memiliki berat tanah 468,3 gr dengan 3 genggam tangan pengambilan sampel tanah. Kedua dosis ini digunakan untuk menyebuhkan sakit penyakit.

Berdasarkan hasil penelitian diketahui bahwa pengobatan terhadap sakit dengan menggunakan tanah hanya dilakukan terhadap penyakit atau sakit yang dialami secara umum yaitu terhadap jenis penyakit yang dialami diluar tubuh. Cara mengobati sakit tersebut ialah digosok/dioleskan pada seluruh badan yang mengalami sakit. Jenis sakit yang diobati antara lain: luka akibat terpotong, bengkak, dan lain-lain.

Lama penyembuhan rata - rata 3 hari untuk pengobatan sakit batuk, sesak napas (asma), kekurangan darah (HB rendah), sakit kuning, kepala sakit, muntahber (BAB), badan sakit, sedangkan luka membutuhkan waktu yang cukup lama yakni \pm 1 minggu. Pada saat melakukan pengobatan, pasien dilarang untuk mandi selama pengobatan ( \pm 3 hari). Perlu menjaga pola makan, tidak diizinkan untuk menggonsumsi makanan yang berminyak dan penyedap rasa kecuali garam. Sebab ini bisa dapat menimbulkan sakitnyakembali lagi. 
Tabel 2. Cara pengobatan penyakit oleh masyarakat Kampung Mapura

No. Cara pengobatan Jenis penyakit

1. Digosok/dioles pada seluruh Sesak napas (asma), kekurangan darah (HB badan rendah), sakit kuning, muntahber (BAB), badan sakit.

2. Digosok sekitar area kepala Kepala sakit

3. Digosok dileher dan turun ke Batuk dada

4. Digosok/dioles sekitar luka Luka Sumber : Hasil wawancara, 2018

Berdasarkan hasil penelitian, pasien yang melakukan pengobatan tradisional hanya sering-sering saja, atau pada saat sakit sehingga mereka melakukan pengobatan. Masyarakat yang melakukan pengobatan tradisional, mulai dari sejak menikah, ada yang dari sejak kecil sampai sekarang, ada yang baru pertama kali melakukannya.

Dalam mengobati pasien tidak mematok harga/biaya pengobatan meskipun tanah tersebut disediakan oleh dokter kampung dalam bentuk pengobatan tradisional. Biasanya pasien selesai melakukan pengobatan dan dengan sukarela mereka membayar, namun ada yang bayar dengan uang, kain, dan barang (bahan makanan).

Alasan Masyarakat yang Menggunakan Pengobatan

Berdasarkan hasil penelitian, masyarakat menyatakan bahwa pengobatan tradisional ini dapat memulihkan tubuh yang lemah menjadi kuat. Menurut mereka juga sejak jaman dulu belum ada pengobatan medis, sehingga mereka menggunakan pengobatan tradisional untuk dapat menyembuhkan sakit yang mereka derita.

Tradisi diartikan sebagai sebuah rutinitas atau perilaku yang dilakukan berulang-ulang oleh suatu masyarakat tertentu. Masyarakat percaya kepada pengobatan tradisional karena melihat dan berdasarkan pengalaman orang tua atau nenek moyang mereka yang berhasil menyembuhkan orang lain. Oleh karena dalam tradisi juga kepercayaan dapat tumbuh dan berkembang. Kepercayaan terhadap pengobatan tradisonal dalam hal ini dapat diartikansebagai warisan nenek moyang.

\section{Persepsi Masyarakat Tehadap Kesehatan Modern}

Pengobatan secara modern sebenarnya telah lama dikenal oleh masyarakat Kampung Mapura namun hanya merupakan pengobatan alternatif. Masyarakat Kampung Mapura masih mengandalkan pengobatan tradisional sebelum berobat ke Pustu/Pukesmas terdekat. Masyarakat Kampung Mapura tidak melupakan pengetahuan tradisional. Pengobatan tersebut merupakan pengetahuan yang sangat penting, karena hasil khasiatnya sangat memuaskan tidak berbeda dengan pengobatan secara modern. Biaya yang dikeluarkan untuk pengobatan tradisional sangat minim bahkan hampir tidak ada. Hal ini disebabkan karena bahan yang 
dibutuhkan untuk pengobatan telah tersedia baik di hutan, kebun, maupun pekarangan rumah tanpa membeli.

\section{Pola Transfer Pengetahuan Tradisional}

Pengetahuan mengenai pengobatan tradisional pada dasarnya adalah bersifat pewarisan dalam keluarga. Dalam hal ini keluarga menjadi tempat penting dalam mempertahankan pengetahuan mengenai pengobatan tradisional. Pengalaman orang tua dalam menggunakan pengobatan tradisional merupakan sosialisasi pengobatan tradisional bagi anak. Pemanfaatan pengobatan tradisional terutama adalah untuk mengobati penyakit yang menimpa diri sendiri atau anggota keluarga. Pemanfaatan pengetahuan pengobatan tradisional juga digunakan untuk mengobati orang lain atau tetangga. Mengobati orang lain atau tetangga pada dasarnya bukan untuk mendapatkan uang melainkan hanya untuk menolong orang yang sakit tersebut. Hal tersebut dilakukan oleh pengobatan tradisional karena menganggap pengetahuan yang mereka miliki juga bukan sepenuhnya berasal dari upaya mereka melainkan dari moyang dan orang tua mereka.

Pemanfaatan tanah sebagai pengobatan tardisional telah dilakukan oleh masyarakat Kampung Mapura. Berdasarkan hasil wawancara yang dilakukan pada masyarakat tersebut mengenai pola pewarisan pengetahuan meliputi jenis tanah, pemanfaatan sebagai pengobatan, diketahui bahwa pengetahuan tersebut berasal dari warisan generasi terdahulu (nenek moyang) dan pengalaman mereka. Pewarisan pengetahuan tentang pemanfaatan tanah sebagai pengobatan tradisional dilakukan secara langsung dengan menggunakan penilain tertentu dari orang tua adat tetua adat memberikan kepada anak. Pola transfer pengetahuan dilakukan secara langsung tetapi pada waktu tertentu.

\section{DAFTAR PUSTAKA}

Asmino P. 1995. Pengalaman pribadi dengan pengobatan alternatif. Jakarta: Airlangga University Press.

Dermawan R. 2013. Peran battara dalam pengobatan tradisional pada masyarakat komunitas Dayak Agabag di Kecamatan Lumbis kabupaten Nunukan. Jurnal Sosiologi Kontruksi, Vol 1 dan 4.http://ejournal.sos.fisipunmul.ac.id/. Diakses Multinet 9 Mey 2016.

Yulipriyanto H. 2010. Biologi tanah dan strategi pengelolaannya. Edisi pertama. Graha Ilmu. 